\title{
Correlation between reticulum ribosome-binding protein 1 (RRBP1) overexpression and prognosis in cervical squamous cell carcinoma
}

Jiaqi Zhu

Harbin Medical University Cancer Hospital

Ruixue Zhao

Harbin Medical University Cancer Hospital

Wei Xu

Harbin Medical University Cancer Hospital

Jing Ma

Harbin Medical University Cancer Hospital

Xin Ning

Harbin Medical University Cancer Hospital

Rong Ma ( $\nabla$ dr_marong2017@126.com )

Harbin Medical University Cancer Hospital

Fanling Meng

Harbin Medical University Cancer Hospital

\section{Research}

Keywords: Cervical squamous cell carcinoma (SCC), Endoplasmic reticulum ribosome binding protein 1 (RRBP1), Immunohistochemistry, Western blotting, qRT-PCR, Diagnosis, Prognosis

Posted Date: March 26th, 2020

DOI: https://doi.org/10.21203/rs.3.rs-17769/v1

License: (c) (1) This work is licensed under a Creative Commons Attribution 4.0 International License. Read Full License 


\section{Abstract}

Purpose: The aim of this study was to investigate the relationship between endoplasmic reticulum ribosomal binding protein 1 (RRBP1) expression in cervical squamous cell carcinoma tissues and its poor prognosis. RRBP1 is a nascent transporter on the rough endoplasmic reticulum. Its function is to regulate the transport and secretion of proteins in cells, and to relieve endoplasmic reticulum (ER) stress, thereby promoting tumor cell proliferation.

Methods: The expression levels of RRBP1 in 96 cervical squamous cell carcinoma tissues were detected by immunohistochemistry. Western blot and qRT-PCR were used to compare the expression levels of RRBP1 in cervical squamous cell carcinoma tissues and normal cervical tissues. Then the chi-square test was used to analyze the results of immunohistochemistry. Finally, the Kaplan-Meier method was used to analyze the results by log-rank test and Cox regression (proportional risk model).

Result: The overexpression of RRBP1 in cervical squamous cell carcinoma tissues was related to FIGO stage $(P=0.030)$, tissue differentiation $(P=0.047)$, lymph node metastasis $(P=0.031)$, and was not related to the patient age $(P=0.667)$. Univariate survival analysis showed that the prognosis was associated to the expression level of RRBP1 $(P=0.045)$ and lymph node metastasis $(P=0.001)$. Analysis of multi-factor survival cox model proved that RRBP1 was an independent prognostic factor.

Conclusion: RRBP1 was overexpressed in cervical squamous cell carcinoma tissues, indicating that RRBP1 may be a new tumor marker for early diagnosis, treatment and prognosis of cervical squamous cell carcinoma, and it will provide help for individualized treatment and prognosis of cervical squamous cell carcinoma in the future.

\section{Introduction}

Cervical cancer is a common malignant tumor in gynecology. It was reported that in 2012, a total of 530,000 cases of cervical cancer were diagnosed worldwide, of which $85 \%$ occurred in underdeveloped areas.(1) Because of the distribution of medical source was uneven and the system of cervical cancer screening was unsound and it will be add 45 million new patients with cervical cancer in the next half century.(2) Cervical squamous cell carcinoma is a common pathological type of cervical cancer. Although conventional treatments for early cervical squamous cell carcinoma include surgery and chemotherapy, postoperative complications and poor prognosis of cervical squamous cell carcinoma still pose a threat to women's health. Therefore, we still need to continue to explore the prognostic factors and potential therapeutic targets of cervical squamous cell carcinoma.

Endoplasmic reticulum ribosomal binding protein 1 is a nascent transporter with a molecular weight of $180 \mathrm{KD}$ located on the rough endoplasmic reticulum membrane. Its primary structure contains three different domains, the most characteristic of which is 10 The amino acids were repeated in series 54 times in the vicinity of the $-\mathrm{NH} 2$ terminus.(3)And Its function is to regulate the transport and secretion of proteins in some cells in mammalian cells. From previous studies, we found that in myogenic progenitor 
cells, Low expression of RRBP1 contributes to excessive deposition of extracellular matrix (ECM).(4) RRBP1a, RRBP1b can be expressed in early embryonic development and adult tissues of Xenopus laevis. (5) At the same time, RRBP1 is also involved in the process of intestinal maturation and is expressed during the osteoblast differentiation and at the neuromuscular junction.(6-8) In recent years, as the deepening of the research, we found that the expression of cytosolic anaplastic lymphoma kinase (ALK) in the epithelioid inflammatory myofibroblastic sarcoma of RRBP1-ALK fusion increased with the nuclear week, and found a new carcinogenic mechanism of recurrent ALK.(9) Recently, we also learned that overexpression of RRBP1 in lung cancer may be involved in the regulation of mRNA stability of the unfolded protein response (UPR) component (ATF6 and GRP78), thereby reducing ER stress and helping tumor cell survival.(10) In addition, we also found that RRBP1 is overexpressed in a variety of tumor cells, including liver cancer, prostate cancer, colorectal cancer, lung cancer, Her-2 (+) breast cancer, esophageal cancer, endometrial cancer and ovarian cancer.(10-17)

However, to date, few has explored the relationship between RRBP1 overexpression and the prognosis of cervical squamous cell carcinoma. The purpose of the present study was to investigate whether RRBP1 was overexpressed in cervical squamous cell carcinoma through immunohistochemistry, Western blotting and qRT-PCR. Statistical methods were used to explore the correlation between the overexpression of RRBP1 and the prognosis of cervical squamous cell carcinoma.

\section{Materials And Methods}

\subsection{Patients and clinical samples}

Confirmed by the Department of Pathology for Harbin Medical University Cancer Hospital, gathered of 96 samples of patients with cervical squamous cell carcinoma who accepted cervical cancer staging surgery at the Harbin Medical University Cancer Hospital from January 2010 to December 2012. (not accepted any treatment before surgery, including immunotherapy, chemotherapy and radiotherapy). Clinical samples were processed by experienced pathologists through fixed, dehydrated, transparent, waxtransparent, embedded, sliced, patched, stained, transparent, sealed made into Paraffin embedded samples. Clinical pathological features including age, lymph node metastasis, tissue differentiation, and clinical stage (according to cervical cancer 2009 FIGO staging) were found by Hospital medical record system. The follow-up period was from the day of surgery to November 2018 (the follow-up date was 11105 months, average 81 months). The study was ratified by the Harbin Municipal Ethics Committee and supported by the Harbin Medical University in China. All patients submit Informed consents.

\subsection{Immunohistochemistry}

According to the manufacturer's instructions, the purchased RRBP1 antibody (1: 1000, RRBP1 antibody, Abcam, Ab95983, UK) was diluted. In short, 98 paraffin sections fixed from formalin of the Tumor Hospital of Harbin Medical University were dewaxed. In order to eliminate the effect of endogenous peroxidase, pretreatment with $3 \% \mathrm{H}_{2} \mathrm{O}_{2}$ solution for 10 minutes at room temperature. Antigen retrieval was achieved by microwave in citrate buffer $\mathrm{pH} 6.0$ for 30 minutes. Block with the same source for serum 
of the secondary antibody for 15-30 minutes, add all the samples to the primary antibody diluted with anti-RRBP1 antibody in a ratio of (1:1000), and incubate at $4{ }^{\circ} \mathrm{C}$ for overnight, and rewarmed, and rinse with phosphate buffered saline (PBS) 3 minutes $\times 5$ times. Next the biotin-labeled secondary antibody (goat anti-rabbit IgG-HRP, wanleibio, WLA023, China) was further added dropwise and incubated at $37^{\circ} \mathrm{C}$ for 30 minutes, and the cells were further washed with PBS for 3 minutes $\times 5$ times. Then Immunoperoxidase staining was developed for 5 minutes using DAB chromogen and incubated at room temperature for 30 minutes to 1 hour. Finally, it was washed with PBS for 3 minutes $\times 5$ times and counterstained with hematoxylin. We used a diluent instead of a primary antibody as a negative control. Immunohistochemistry results were analyzed by two experienced pathologists without understand of clinical information, and RRBP1 staining was analyzed by semi-quantitative methods. The staining intensity score was colorless (0), light yellow (1), brownish yellow (2), tan (3); Total percentage of positive cells scored 0 means $<5 \% ; 1$ means $5-25 \% ; 2$ means: $26-50 \% ; 3$ means $51-75 \%$; 4 means $>75 \%$. The score for each sample is calculated by the product of two values. The score $(\geq 4)$ was evaluated as high expression and the score (<4) was evaluated as low expression.

\subsection{Western blot analysis}

All fresh surgical specimen tissues $(n=36)$ were frozen in a $-80^{\circ} \mathrm{C}$ ultra-low temperature freezer, and the experimental reagents and polyacrylamide gels were prepared according to the manufacturer's instructions. Firstly, in order to extract the protein, aliquoted the lysate (containing 1\% PMSF) according to the needed of the experiment, and added each sample to the lysate, and left it on ice for 5 minutes. The lysate was transferred to a centrifuge tube and centrifuged at $12000 \mathrm{rpm}$ for 5 minutes at $4{ }^{\circ} \mathrm{C}$,and took the supernatant and stored at $-20^{\circ} \mathrm{C}$. Then total protein was quantified used the purchased BCA protein concentration determination kit (wanleibio, WLA004, China). The complex protein mixture was separated by SDS-PAGE (wanleibio, WLA013, China) and transferred to a PVDF membrane (Millipore, IPVH00010, USA) in a conventional manner. So as to incubate the primary antibody, the purchased RRBP1 antibody (1: 1000, RRBP1 antibody, Abcam, Ab95983, UK) was incubated in a buffer at $4{ }^{\circ} \mathrm{C}$ overnight. Then incubated the secondary antibody through goat anti-rabbit IgG-HRP (1:5000, Goat anti-rabbit IgGHRP $\llbracket$ wanleibio, WLA023, China) was incubated for 45 minutes at $37^{\circ} \mathrm{C}$. Finally, the configured chemiluminescent reagent was mixed with the membrane, shaken at room temperature for 5 minutes, the residual liquid was placed in the X-ray film at a dark room before final development, and the exposure time was appropriately adjusted according to the strength of the signal, and the image processing system (Gel-Pro-Analyzer software) analyzed the optical density value of the target band. The $\beta$-actin antibody (wanleibio, WL01845, China) was used as an internal reference antibody.

\subsection{Real-time PCR analysis}

First mRNA was extracted from fresh surgical samples $(n=36)$ according to the manufacturer's instructions and the concentration of RNA in each sample was determined used a UV spectrophotometer NANO 2000 (UV spectrophotometer NANO 2000, Thermo, USA). The cDNA was then synthesized in a PCR instrument (Real-Time PCR, Exicycler 96, BIONEER, Korea) used Super M-MLV reverse transcriptase (BioTeke, PR6502, Beijing), and the products were subjected to quantitative fluorescence analysis. This 
experimental analysis method used the $2-\triangle \triangle C T$ method. PCR amplification conditions: Incubated at $94.00{ }^{\circ} \mathrm{C}$, for 5 minutes, incubated at $94.00{ }^{\circ} \mathrm{C}$, for 10 seconds, incubated at $60.00{ }^{\circ} \mathrm{C}$, for 20 seconds, incubated at $72.00{ }^{\circ} \mathrm{C}$, for 30 seconds. Scanned, went to line 2, Cycle 40 , incubated at $72.00{ }^{\circ} \mathrm{C}$, for 2 minutes 30 seconds, incubated at $40.00{ }^{\circ} \mathrm{C}$, for 1 minutes 30 seconds, melted $60{ }^{\circ} \mathrm{C}$ to $94{ }^{\circ} \mathrm{C}$, Every 1.0 ${ }^{\circ} \mathrm{C}$, 1 seconds, incubated at $25.00{ }^{\circ} \mathrm{C}$, for $1-2$ minutes. The primer sequence of RRBP1-F is $5^{\prime}-$

TCCATCCAGAGTCTCACTTC-3 ', and the primer sequence of RRBP1-R is 5'-GCCCTCGTTGAACACCAT-3'. The primer sequence of GAPDH-F is $5^{\prime}$-GGCACCCAGCACAATGAA-3 ', and the primer sequence of GAPDH$\mathrm{R}$ is 5'-TAGAAGCATTTGCGGTGG-3'. The $\beta$-actin antibody (wanleibio, WL01845, China) was used as an internal reference antibody.

\subsection{Statistical analysis}

We utilized chi-square test to analyze the results of immunohistochemistry, and applied the Kaplan-Meier method to estimate the total survival (OS) and disease-free survival (DFS) of cervical cancer, and applied log rank test. Finally, multivariate analysis was assessed according to Cox regression (proportional risk model). A P $<0.05$ was deemed statistically implication. All the above statistical analysis applied Windows SPSS software V25.0 (IBM SPSS. Inc., Chicago, IL, USA).

\section{Results}

\subsection{Patient pathological features}

To analyze the immunity of RRBP1 in cervical squamous cell carcinoma tissues, we used 96 samples without any treatment of cervical cancer tissues from Cancer Hospital of Harbin Medical University. In all samples a total of 45 samples were $>49$ years old, and 51 patients were aged $\leq 49$ years old. Among the collected samples, 38 patients had stage I (according to the 2009 FIGO stage of cervical cancer), and 58 patients with stage II. The clinical and pathological features of the sample are shown in Table 1. 
Table 1

Association analyses between the expression levels of RRBP1 and the clinicopathological characteristics of Cervical squamous cell carcinoma(SCC)

\begin{tabular}{|c|c|c|c|c|}
\hline \multirow{2}{*}{$\begin{array}{l}\text { Variables Patients } \\
\text { n }\end{array}$} & & \multicolumn{2}{|c|}{ RRBP1 expression } & \multirow[t]{2}{*}{$\mathbf{P}^{\mathbf{a}}$} \\
\hline & & Low & High & \\
\hline \multicolumn{5}{|l|}{ All cases } \\
\hline \multicolumn{5}{|l|}{ Age(years) } \\
\hline$₫ 49$ & 45 & 14 & 31 & $P=0.667$ \\
\hline$\leq 49$ & 51 & 19 & 32 & \\
\hline \multicolumn{5}{|l|}{ FIGO stage } \\
\hline $\begin{array}{l}\text { प } \\
\square\end{array}$ & $\begin{array}{l}38 \\
58\end{array}$ & $\begin{array}{l}18 \\
15\end{array}$ & $\begin{array}{l}20 \\
43\end{array}$ & $P=0.030$ \\
\hline \multicolumn{5}{|l|}{ Histological grade } \\
\hline G1 & 23 & 12 & 11 & $P=0.047$ \\
\hline G2/G3 & 73 & 21 & 52 & \\
\hline \multicolumn{5}{|c|}{ lymph node metastasis } \\
\hline No & 83 & 32 & 51 & $P=0.031$ \\
\hline Yes & 13 & 1 & 12 & \\
\hline \multicolumn{5}{|c|}{$\begin{array}{l}\text { FIGO, International Federation of Gynecology and Obstetrics; G1, well differentiated; G2, moderately } \\
\text { differentiated; G3, poorly differentiated; RRBP1, Hematopoietic pre-B cell leukemia transcription facto } \\
\text { (PBX)-interacting protein; }{ }^{\text {a }} \text { Chi-square test. }\end{array}$} \\
\hline
\end{tabular}

\subsection{Endoplasmic reticulum ribosomal binding protein 1 (RRBP1) in cervical squamous cell carcinoma tissue was overexpression}

For the expression of RRBP1 in cervical squamous cell carcinoma, we performed immunohistochemistry on 96 samples, and the results showed that RRBP1 was located in the nucleus and cytoplasm of tumor cells (Fig. 2). As shown in Table 1, it total 12 patients showed low expression and 84 patients showed high expression. In addition, the high expression of RRBP1 in cervical squamous cell carcinoma tissues was connected to FIGO stage $(P=0.030)$, tissue differentiation $(P=0.047)$, lymph node metastasis $(P=$ $0.031)$, and was not related to the patient age $(P=0.667)$.

We used 36 fresh surgical specimen samples to analyze the differential expression of RRBP1 among in cervical squamous cell carcinoma and normal cervical tissues through Western blot and qRT-PCR 
(Fig. 1and Fig. 2). Specifically, the expression of RRBP1 protein and the level of mRNA in cervical squamous cell carcinoma tissues was higher than that in normal cervical tissues. (Pख0.001)

\subsection{The relationship between overexpression of RRBP1 in cervical squamous cell carcinoma and its poor prognosis}

We used the Kaplan-Meier method to analyze the overall survival (OS) and disease-free survival (DFS) of 96 samples. As shown in Table 2, univariate survival analysis showed that RRBP1 overexpression and lymph node metastasis were associated with poor prognosis of cervical squamous cell carcinoma. The RRBP1 overexpression overall survival (OS) (Table 2, $\mathrm{P}=0.001$ ) and disease-free survival Period (DFS) (Table 2, $\mathrm{P}<0.001$ ), and the lymph node metastasis overall survival (OS) (Table 2, $\mathrm{P}=0.045$ ) and diseasefree survival (DFS) (Table 2, $\mathrm{P}=0.016)$. 
Table 2

Univariate survival analysis of OS and DFS in 96 patients with Cervical squamous cell carcinoma(SCC)

\begin{tabular}{|c|c|c|c|c|c|c|c|}
\hline \multirow[t]{3}{*}{ Variables } & \multirow[t]{3}{*}{$\mathrm{n}$} & \multicolumn{2}{|l|}{ OS } & $P^{a}$ & \multicolumn{2}{|l|}{ DFS } & $\mathrm{Pa}^{\mathrm{a}}$ \\
\hline & & \multicolumn{3}{|c|}{ Mean \pm SE(month) } & \multicolumn{3}{|c|}{ Mean \pm SE(month) } \\
\hline & & \multicolumn{3}{|l|}{$95 \% \mathrm{Cl}$} & \multicolumn{3}{|l|}{$95 \% \mathrm{Cl}$} \\
\hline \multicolumn{8}{|l|}{ Age(years) } \\
\hline$\varangle 49$ & 45 & $96 \pm 3$ & $91-102$ & $\begin{array}{l}P= \\
0.200\end{array}$ & $91 \pm 4$ & $82-99$ & $\begin{array}{l}P= \\
0.164\end{array}$ \\
\hline$\leq 49$ & 51 & $88 \pm 4$ & $81-95$ & & $80 \pm 5$ & $70-89$ & \\
\hline \multicolumn{8}{|l|}{ FIGO stage } \\
\hline $\begin{array}{l}0 \\
0\end{array}$ & $\begin{array}{l}38 \\
58\end{array}$ & $\begin{array}{l}93 \pm 3 \\
91 \pm 3\end{array}$ & $\begin{array}{l}86-100 \\
85-97\end{array}$ & $\begin{array}{l}P= \\
0.767\end{array}$ & $\begin{array}{l}85 \pm 5 \\
84 \pm 4\end{array}$ & $\begin{array}{l}76-95 \\
76-93\end{array}$ & $\begin{array}{l}P= \\
0.667\end{array}$ \\
\hline \multicolumn{8}{|l|}{ Histological grade } \\
\hline G1 & 23 & $95 \pm 3$ & $90-100$ & $\begin{array}{l}P= \\
0.255\end{array}$ & $89 \pm 6$ & $77-100$ & $\begin{array}{l}P= \\
0.217\end{array}$ \\
\hline G2/ G3 & 73 & $91 \pm 3$ & $85-96$ & & $84 \pm 4$ & $76-91$ & \\
\hline \multicolumn{8}{|l|}{$\begin{array}{l}\text { lymph node } \\
\text { metastasis }\end{array}$} \\
\hline No & 83 & $94 \pm 2$ & $89-99$ & $\begin{array}{l}P= \\
0.045\end{array}$ & $88 \pm 3$ & $82-95$ & $\begin{array}{l}P= \\
0.016\end{array}$ \\
\hline Yes & 13 & $82 \pm 5$ & $71-92$ & & $65 \pm 9$ & $47-83$ & \\
\hline \multicolumn{8}{|l|}{ RRBP1 } \\
\hline Low expression & 38 & $97 \pm 1$ & $95-99$ & $\begin{array}{l}P= \\
0.001\end{array}$ & $96 \pm 2$ & $93-100$ & $P \otimes 0.001$ \\
\hline High expression & 58 & $87 \pm 3$ & $81-94$ & & $77 \pm 5$ & $68-86$ & \\
\hline $\begin{array}{l}\text { FIGO, Internationa } \\
\text { differentiated; G3 } \\
\text { (PBX)-interacting }\end{array}$ & dif & $\begin{array}{l}\text { of Gyn } \\
\text { entiate } \\
\text { overall }\end{array}$ & $\begin{array}{l}\text { gy and } \\
\text { BP1, He } \\
\text { al; DFS }\end{array}$ & $\begin{array}{l}\text { trics; G } \\
\text { poietic } \\
\text { ase-free }\end{array}$ & $\begin{array}{l}\text { ell diffe } \\
- \text { B cell le } \\
\text { rvival; }{ }^{a}\end{array}$ & $\begin{array}{l}\text { ated; G2, } \\
\text { nia trans } \\
\text { rank test }\end{array}$ & $\begin{array}{l}\text { erately } \\
\text { ion factor }\end{array}$ \\
\hline
\end{tabular}

In addition, Multivariate survival analysis was assessed by Cox regression (proportional risk model), as show in Fig. 4, RRBP1 was an independent prognostic factor for cervical squamous cell carcinoma, and its overall survival (OS) (Table $3,95 \otimes \mathrm{Cl}=1.531-85.265, \mathrm{P}=0.018$ ) and disease-free survival (DFS) (Table 3, 95\% Cl = 2.009-111.098, $\mathrm{P}=0.008$ ). 
Table 3

Multivariate survival analysis of OS and DFS in 96 patients with Cervical squamous cell carcinoma(SCC)

\begin{tabular}{|c|c|c|c|c|c|c|}
\hline \multirow{3}{*}{$\begin{array}{l}\text { Variables } \\
\begin{array}{l}\text { lymph node } \\
\text { metastasis }\end{array}\end{array}$} & \multirow{2}{*}{\multicolumn{3}{|c|}{$\begin{array}{l}\text { OS } \\
\operatorname{Exp}(B) 95 \% C l P^{a}\end{array}$}} & \multirow{2}{*}{\multicolumn{3}{|c|}{ 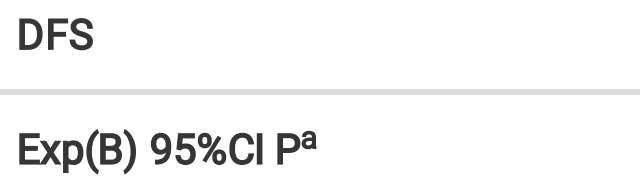 }} \\
\hline & & & & & & \\
\hline & 1.770 & $0.697-4.495$ & $\begin{array}{l}P= \\
0.230\end{array}$ & 1.855 & $0.780-4.409$ & $\begin{array}{l}P= \\
0.162\end{array}$ \\
\hline RRBP1 & 11.424 & $\begin{array}{l}1.531- \\
85.265\end{array}$ & $\begin{array}{l}P= \\
0.018\end{array}$ & 14.939 & $\begin{array}{l}2.009- \\
111.098\end{array}$ & $\begin{array}{l}P= \\
0.008\end{array}$ \\
\hline
\end{tabular}

\section{Discussion}

In the present study, we analyzed the association of endoplasmic reticulum ribosomal binding protein 1 (RRBP1) expression in cervical squamous cell carcinoma and its poor prognosis. We proved that RRBP1 expression in cervical squamous cell carcinoma tissues was significantly higher than that in normal cervical tissues by Western blot and qRT-PCR analysis of RRBP1 protein expression and mRNA level analysis, and it indicates that RRBP1 may participated in the proliferation, invasion and metastasis of cervical squamous cell carcinoma. To the best of our knowledge, this is the first to publish evaluation of endoplasmic reticulum ribosomal binding protein 1 (RRBP1) overexpressing in cervical cancer tissue. In our study, we found that the overexpression of RRBP1 in cervical squamous cell carcinoma tissues was related to FIGO stage $(P=0.030)$, tissue differentiation $(P=0.047)$, and lymph node metastasis $(P=$ $0.031)$, which was not related to patient age $(P=0.667)$. Univariate survival analysis showed that RRBP1 overexpression and lymph node metastasis affected the overall survival (OS) and disease-free survival (DFS) of patients. Multivariate survival analysis showed that RRBP1 was an independent prognostic factor.

Endoplasmic reticulum ribosomal binding protein 1 (RRBP1) was originally explored in S. cerevisiae and its primary structure with highly repetitive tandem sequences and demonstrated to be located on the endoplasmic reticulum membrane.(3) Because of its unusually long 51 UTR in its secondary structure, it may be directly involved in the recruitment of ribosomal subunits and initiate translation.(11) According to a large number of previous studies, it was found that RRBP1 may interact with kinesin family member $5 B$ (KIF5B) to participate in the accumulation of autophagosomes in tumor cells, and overexpression of RRBP1 causes ER stress to be alleviated and stabilized, leads to the accumulation of unfolded and folded proteins (UPR) in the endoplasmic reticulum, resulting in abnormal protein function, which can lead to cancer.(18) Recently, overexpression of rrbp1 was found in liver cancer, prostate cancer, colorectal cancer, lung cancer, Her-2 (+) breast cancer, esophageal cancer, in endometrial cancer and in ovarian cancer and was closely associated with poor prognosis. $(9,10,12-17)$ 
This study demonstrated the relationship between high expression of RRBP1 and its poor prognosis of cervical squamous cell carcinoma. We have the equally method as the previous study, which proved that RRBP1 plays a significant role in carcinogenesis and tumor progression, and it provides a powerful help for early diagnosis and individualized treatment of cervical squamous cell carcinoma from now on. Our samples were all squamous cell carcinoma, so more pathological types such as adenocarcinoma and adeno-squamous carcinoma will need to fully evaluate the relationship between the high expression of RRBP1 in cervical cancer and its prognosis.

\section{Conclusion}

In conclusion, this present research proves that endoplasmic reticulum ribosomal binding protein 1 (RRBP1) was overexpressed in cervical squamous cell carcinoma tissues and influence patients' diseasefree survival (DFS) and overall survival (OS). RRBP1 as an independent prognostic factor for cervical squamous cell carcinoma, and It was indicated that RRBP1 may be become a new tumor marker for cervical squamous cell carcinoma, and will provide great help in early diagnosis, individualized treatment and monitoring of poor prognosis for cervical squamous cell carcinoma, and inhibitors of RRBP1 may be used to treat cancer to some extent.

\section{Abbreviations}

RRBP1

Endoplasmic ribosome-binding protein 1

ER

Endoplasmic reticulum

SCC

Cervical squamous cell carcinoma

qRT-PCR

Quantitative real-time polymerase chain reaction

FIGO

Federation International of Gynecologie and Obstetrigue

OS

Overall survival

DFS

Disease-free survival

ECM

Extracellular matrix

ALK

Anaplastic lymphoma kinase

UPR

Unfolded protein response 
PBS

Phosphate buffered saline

\section{Declarations}

\section{Ethics approval and consent to participate}

This study was approved by the Medical Ethics Committee of The Affiliated Tumor Hospital of Harbin Medical University. All procedures were performed by the ethical standards of our institutional research committee. Written informed consent was obtained from each participant by the institutional guidelines.

\section{Consent for publication}

Informed consent was obtained from all participants for publication.

\section{Availability of data and materials}

The data used and analyzed during the current study are available from the corresponding author on reasonable request.

\section{Competing interests}

The authors declare that they have no competing interests.

\section{Funding}

This work was supported by grants of the Liande Wu Science Foundation for Young Scholars of Harbin Medical University Cancer Hospital (WLD-QN1705) and the Postdoctoral Research Startup Fund of Heilongjiang Province (LBH-Q16162) and Outstanding Young Scholars fund of Harbin Medical University Cancer Hospital (JCQN2019-05).

\section{Authors' contributions}

JQZ: data acquisition and manuscript writing, RXZ: quality control of data review, WX and JM: follow up and quality control of data, NX: study concept and design.

\section{Acknowledgments}

We express our thanks to Dr. Qi Huang for the evaluation procedures.

\section{References}

1. Barrera-Ramirez J, Lavoie JR, Maganti HB, Stanford WL, Ito C, Sabloff M, et al. Micro-RNA Profiling of Exosomes from Marrow-Derived Mesenchymal Stromal Cells in Patients with Acute Myeloid Leukemia: Implications in Leukemogenesis. Stem Cell Rev Rep. 2017;13(6):817-25. 
2. Simms KT, Steinberg J, Caruana M, Smith MA, Lew JB, Soerjomataram I, et al. Impact of scaled up human papillomavirus vaccination and cervical screening and the potential for global elimination of cervical cancer in 181 countries, 2020-99: a modelling study. Lancet Oncol. 2019;20(3):394-407.

3. Wanker EE, Sun Y, Savitz AJ, Meyer DI. Functional characterization of the 180-kD ribosome receptor in vivo. J Cell Biol. 1995;130(1):29-39.

4. Fry CS, Kirby TJ, Kosmac K, McCarthy JJ, Peterson CA. Myogenic Progenitor Cells Control Extracellular Matrix Production by Fibroblasts during Skeletal Muscle Hypertrophy. Cell Stem Cell. 2017;20(1):56-69.

5. Liu GH, Mao CZ, Wu HY, Zhou DC, Xia JB, Kim SK, et al. Expression profile of rrbp1 genes during embryonic development and in adult tissues of Xenopus laevis. Gene Expr Patterns. 2017;23-24:1-6.

6. Chang J, Chance MR, Nicholas C, Ahmed N, Guilmeau S, Flandez M, et al. Proteomic changes during intestinal cell maturation in vivo. J Proteomics. 2008;71(5):530-46.

7. Nazarian J, Bouri K, Hoffman EP. Intracellular expression profiling by laser capture microdissection: three novel components of the neuromuscular junction. Physiol Genomics. 2005;21(1):70-80.

8. Zheng Y, Li X, Huang Y, Jia L, Li W. Time series clustering of mRNA and IncRNA expression during osteogenic differentiation of periodontal ligament stem cells. PeerJ. 2018;6:e5214.

9. Lee JC, Li CF, Huang HY, Zhu MJ, Marino-Enriquez A, Lee CT, et al. ALK oncoproteins in atypical inflammatory myofibroblastic tumours: novel RRBP1-ALK fusions in epithelioid inflammatory myofibroblastic sarcoma. J Pathol. 2017;241(3):316-23.

10. Tsai HY, Yang YF, Wu AT, Yang CJ, Liu YP, Jan YH, et al. Endoplasmic reticulum ribosome-binding protein 1 (RRBP1) overexpression is frequently found in lung cancer patients and alleviates intracellular stress-induced apoptosis through the enhancement of GRP78. Oncogene. 2013;32(41):4921-31.

11. Gao W, Li Q, Zhu R, Jin J. La Autoantigen Induces Ribosome Binding Protein 1 (RRBP1) Expression through Internal Ribosome Entry Site (IRES)-Mediated Translation during Cellular Stress Condition. Int J Mol Sci. 2016;17(7).

12. Li T, Wang Q, Hong X, Li H, Yang K, Li J, et al. RRBP1 is highly expressed in prostate cancer and correlates with prognosis. Cancer Manag Res. 2019;11:3021-7.

13. Pan Y, Cao F, Guo A, Chang W, Chen X, Ma W, et al. Endoplasmic reticulum ribosome-binding protein 1 , RRBP1, promotes progression of colorectal cancer and predicts an unfavourable prognosis. $\mathrm{Br} \mathrm{J}$ Cancer. 2015;113(5):763-72.

14. Liang $X$, Sun $S$, Zhang $X$, Wu H, Tao W, Liu T, et al. Expression of ribosome-binding protein 1 correlates with shorter survival in Her-2 positive breast cancer. Cancer Sci. 2015;106(6):740-6.

15. Wang L, Wang M, Zhang M, Li X, Zhu Z, Wang H. Expression and significance of RRBP1 in esophageal carcinoma. Cancer Manag Res. 2018;10:1243-9.

16. Liu S, Lin M, Ji H, Ding J, Zhu J, Ma R, et al. RRBP1 overexpression is associated with progression and prognosis in endometrial endometrioid adenocarcinoma. Diagn Pathol. 2019;14(1):7. 
17. Ma J, Ren S, Ding J, Liu S, Zhu J, Ma R, et al. Expression of RRBP1 in epithelial ovarian cancer and its clinical significance. Biosci Rep. 2019;39(7).

18. Diefenbach RJ, Diefenbach E, Douglas MW, Cunningham AL. The ribosome receptor, $p 180$, interacts with kinesin heavy chain, KIF5B. Biochem Biophys Res Commun. 2004;319(3):987-92.

\section{Figures}

A

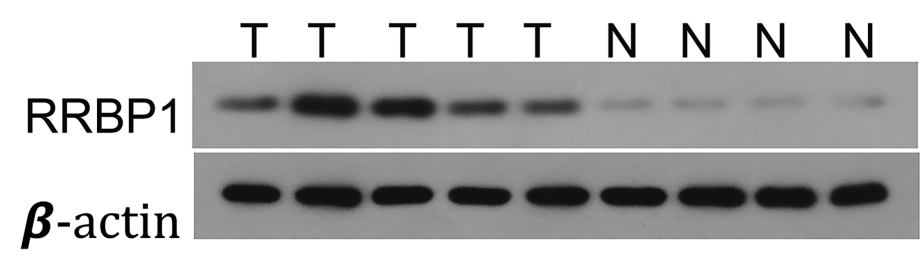

B

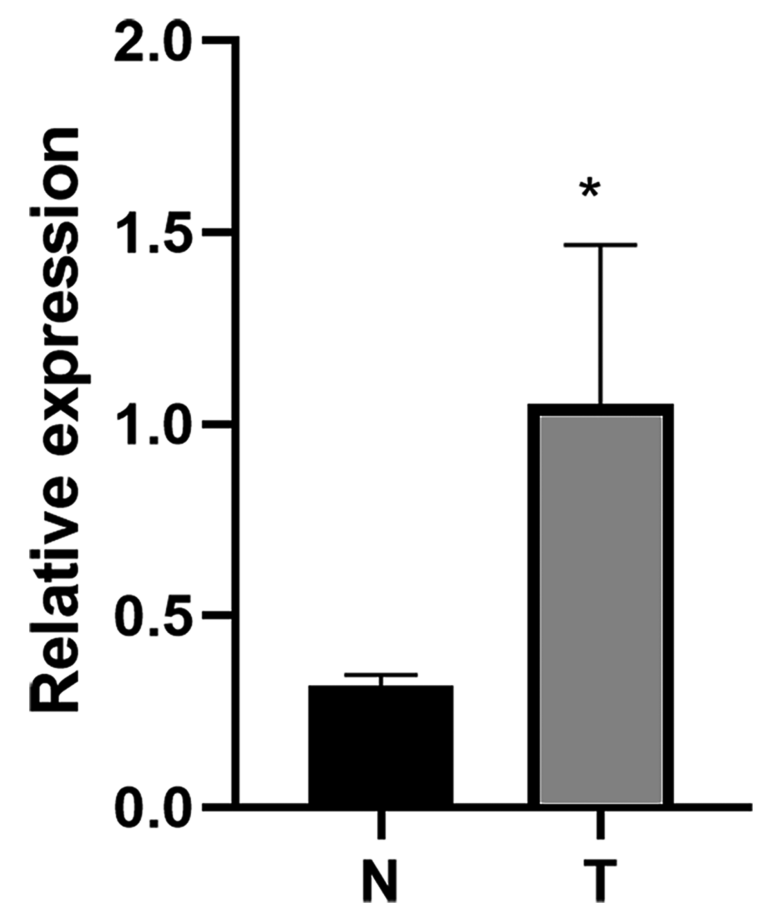

\section{Figure 1}

A, Representative protein samples obtained from frozen normal cervical tissues $(\mathrm{N})$ and cervical squamous cell carcinoma tissues $(T)$ were analyzed by Western blot. The levels of $\beta$-actin were used as an internal control; B, Histogram of pooled data from $N(n=10)$ and cervical squamous cell carcinoma cells (SCCs) ( $n=26)$. RRBP1 expression was elevated in SCCs compared with that in $\mathrm{N}$. The data are presented as the mean $\pm s$. $d(* P<0.001)$. 

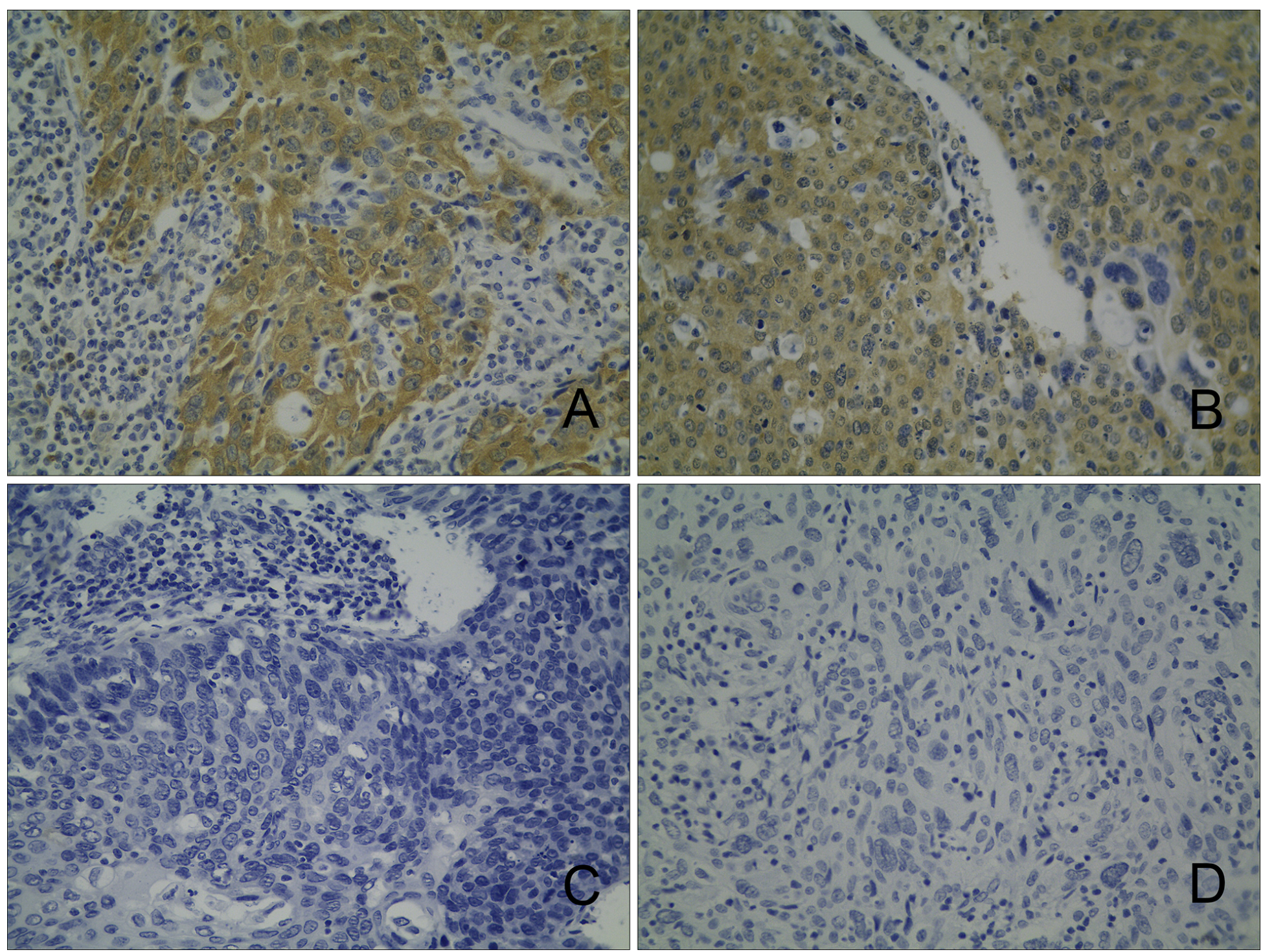

Figure 2

Immunohistochemical staining of RRBP1 in SCC specimens: A and B, High expression of RRBP1 in SCCs; C and D, Low expression of RRBP1 in SCCs. 


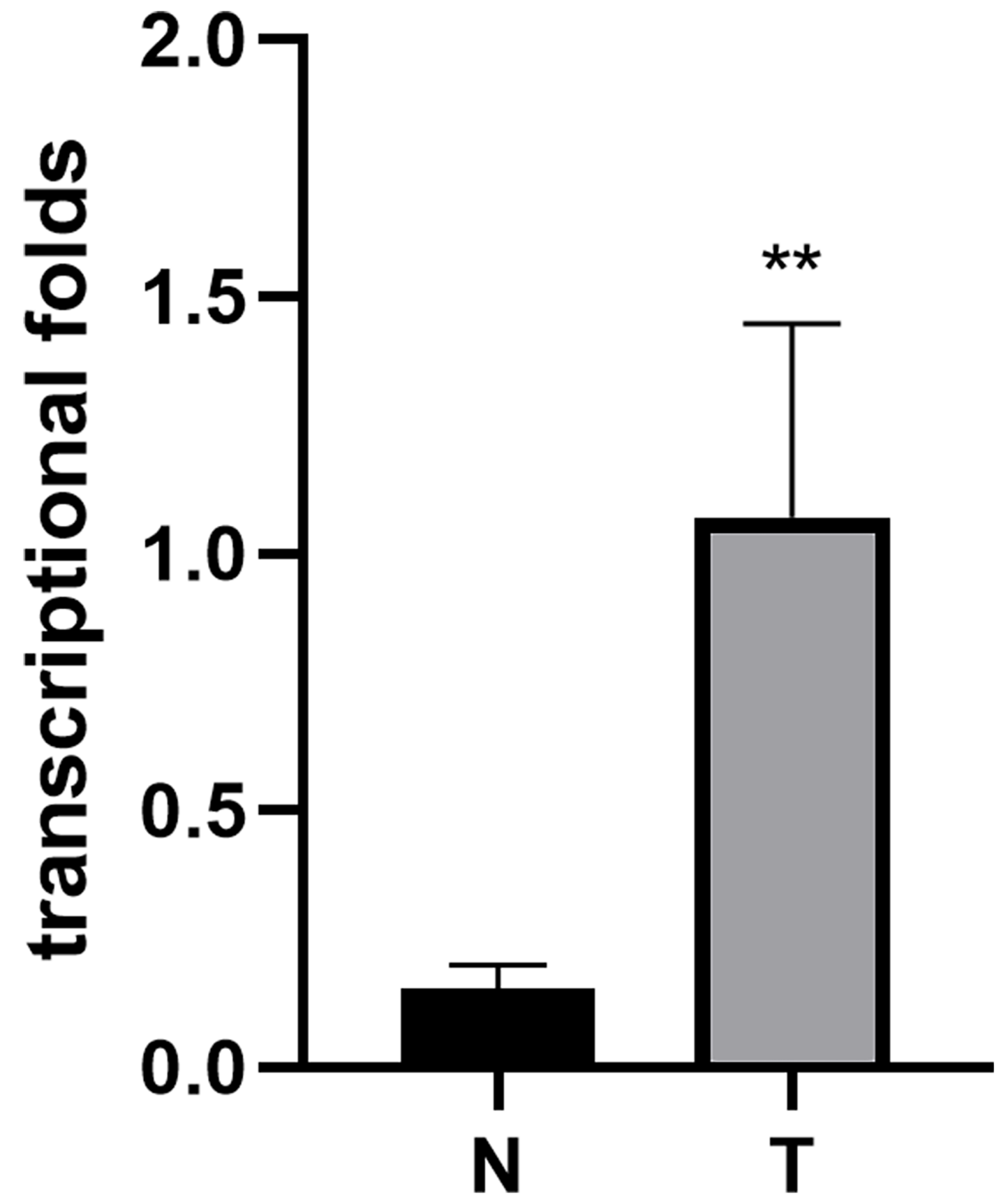

Figure 3

Histogram of RRBP1 mRNA expression in normal cervical tissues and cervical squamous cell carcinoma tissues ( $N$, normal cervical tissues; $T$, cervical squamous cell carcinoma tissues). The levels of $\beta$-actin were used as an internal control, and the RRBP1 mRNA expression was calculated by $2-\Delta \Delta$ Ct method. RRBP1 mRNA expression was elevated in SCCs compared with normal cervical tissues. The data are presented as the mean $\pm s$. $d(* * P<0.001 \Downarrow$. 

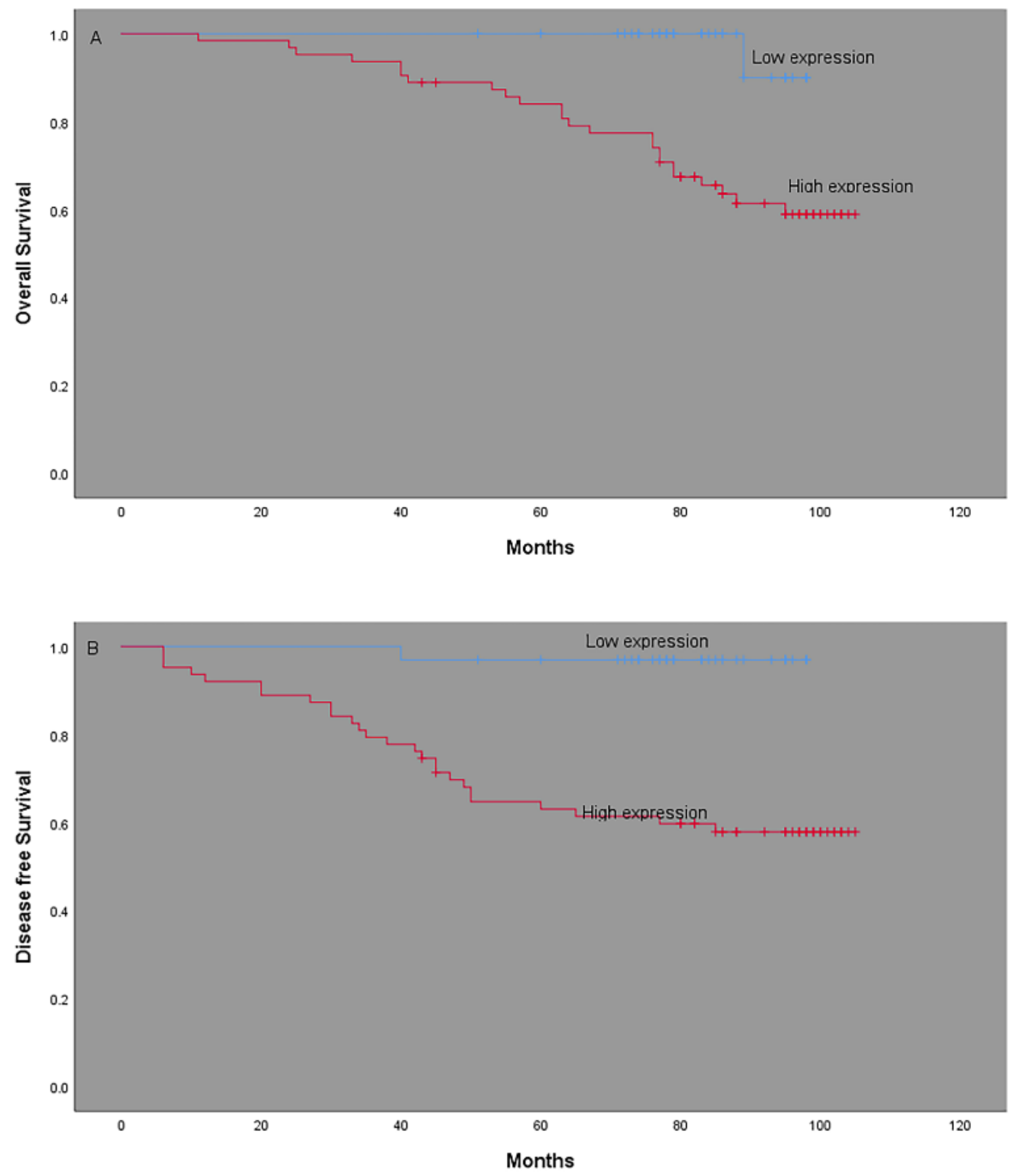

\section{Figure 4}

Kaplan-Meier analysis of overall survival and disease-free survival related to the expression of RRBP1. Patients with high expression of RRBP1 had a poorer prognosis than those with low expression of RRBP1. A, overall survival curves of the SCC according to their RRBP1 expression status, $\mathrm{P} \bowtie 0.018$; $B$, disease-free survival curves of the SCC patients according to their RRBP1 expression status, $\mathrm{P}=0.008$. 